\title{
The Texel-Schneeberg boundary in the Pfossen valley (Merano, NE Italy): geological-structural map and explanatory notes
}

\author{
STEFANO ZANCHETtA (*)
}

\begin{abstract}
The Schneeberg Complex (Merano, NE Italy) was traditionally distinguished from the surrounding Austroalpine basement on the base of its peculiar lithological association made of garnet-rich metapelites, calc-schists, paragonite amphibolites and garnet-amphibole schists, locally with megablasts of garnet and amphibole. As the Schneeberg Complex is considered to be a monometamorphic uni with Alpine metamorphism only, its southern boundary with the polymetemorphic Texel Complex is a key-element in deciphering the tectono-metamorphic evolution of the Austroalpine basement in the western sector of the Eastern Alps.

On the base of the field structural analyses the two units display a common structural evolution at least from the Alpine amphibolite facies event $\left(\mathrm{D}_{2}\right.$ in our reconstruction). In the upper Pfossen valley the marbles, amphibolites and garnet mica schists succession forming the external part of the Schneeberg Complex are folded together with the Texel metapelites in tight structures with step axes, known as «Schlingen» folds. These peculiar structures are due to the $\mathrm{D}_{2}-\mathrm{D}_{3}$ folds interference pattern. The results of the structural analysis in the study area are almost coherent with recent interpretations that propose the entire Schneeberg Complex to represent a greenschist facies crustal scale shear zone (SNFZ, Schneeberg Normal Fault Zone) along which the Texel Complex, containing rocks with eclogitic relics of Alpine age, have been exhumed with a SE direction, starting from the late Cretaceous times.
\end{abstract}

KEY WORDS: Schneeberg Complex, Texel Complex, structural correlation.

\section{RIASSUNTO}

Il limite fra il Complesso di Monteneve e il Complesso di Tessa nell'alta Val di Fosse (Merano, NE Italia): carta geologicostrutturale e note illustrative.

Il Complesso di Schneeberg (o Monteneve, Merano, NE Italia) è stato tradizionalmente distinto dal circostante basamento metamorfico Austroalpino sulla base della sua peculiare associazione litologica costitutita da micascisti a granato, calcescisti, anfiboliti a paragonite e scisti anfibolici a granato, localmente caratterizzati da porfiroblasti di granato ed anfibolo di grana notevole (fino a 10-15 cm). Il limite meridionale del Complesso di Monteneve con il basamento polimetamorfico del Complesso di Texel (o Tessa) riveste un'importanza fondamentale nel contesto dell'evoluzione Alpina di questo settore di catena delle Alpi Orientali dato che, sulla base degli studi fino ad ora esistenti, il Complesso di Schneeberg è stato fino ad ora considerato come un'unità monometamorfica, con metamorfismo di età Alpina.

Le analisi strutturali svolte sul terreno, a corredo della carta geologica allegata, hanno evidenziato un'evoluzione strutturale in comune alle due unità almeno a partire dall'evento metamorfico in facies anfibolitica (associato alla fase deformativa $D_{2}$ nella presente ricostruzione) di età Alpina. In contemporanea all'evento in facies anfibolitica e alla fase $\mathrm{D}_{2}$, le due unità sono state tettonicamente ac-

(*) Dipartimento di Scienze Geologiche e Geotecnologie - Università degli Studi di Milano Bicocca - Piazza della Scienza, 4 - 20126 Milano, Italy. Tel.: +390264482063 - e-mail: stefano.zanchetta@unimib.it coppiate, come evidenziato dalla presenza di miloniti sin- $\mathrm{D}_{2}$ al contatto meridionale fra Schneeberg e Texel. Nel settore superiore della valle di Fosse la parte marginale del Complesso di Schneeberg, è stata successivamente ripiegata insieme al basamento di Tessa a formare pieghe a laccio ad asse quasi-verticale, note come «Schlingen». Queste particolari strutture risultano dall'interferenza fra i sistemi di pieghe $D_{2}$ e $D_{3}$. I risultati derivanti dalle analisi strutturali si inseriscono coerentemente nei modelli recentementi proposti che interpretano l'intero Complesso di Monteneve come una zona di taglio estensionale sviluppata su scala crostale (Schneeberg Normal Fault Zone, SNFZ), lungo la quale il sottostante basamento dell'unità di Texel, contenente eclogiti di età Alpina, è stato esumato in direzione SE a partire dal Tardo Cretaceo.

Termini chiave: Complesso di Schneeberg, Complesso di Texel, correlazione strutturale.

\section{INTRODUCTION}

Since the works of HAMmer (1912) and SANDER (1921) the southern boundary between the crystalline basement of the Texel Complex (TC), in those times considered part of the Ötztal-Stubai complex, and the Schneeberg Complex (SC) has been strongly debated. While the northern boundary of the SC is almost clear, locally characterised by brittle structures indicating the presence of a normal fault between the SC and the Ötztal-Stubai basement to the north, the southern one is not well defined and the Schneeberg Complex was traditionally distinguished form the surrounding Austroalpine polymetamorphic basement on the base of petrographic criteria (MAURACHER, 1981; HoINKES et alii, 1987 for a review).

Recently SöLVA et alii (2005) proposed the existence of a crustal scale extensional shear zone (SNFZ: Schneeberg Normal Fault Zone), including the whole SC, responsible for the SE-directed extrusion of the eclogitesbearing Texel Complex during the Late Cretaceous. Some evidence of such shear zone are present along the northern slope of the Pfelders valley whereas, moving westward, the shear zone disappears and the TC-SC boundary is highlighted only by the peculiar lithologies of the external part of the SC.

The aim of this work is to analyse in detail the tectonic evolution of the two units close to the SW termination of the SC (upper Pfossen, Lazins, Ziel and Pfelders valleys) where the existence of complex fold interference pattern highlighted by reliable structural markers (marbles, calc-schists and amphibolites layers interbedded with gneiss and mica schists) give the opportunities to solve the structural relationships and the succession of deformation events that affected the two units. 
Fig. 1 - Tectonic scheme of the Alpine orogenic belt $(a)$ and of the western sector of the Eastern Alps with the study area. SLG u.: San LeonhardJaufen unit; C.u.: Cervina unit; SV u.: SchennaVerdins unit; MTS: Marlengo Tectonic Slice; SNFZ: Schneeberg Normal Fault Zone; PSCB SZ: Pennes-Stilves-Corno Bianco Shear Zone; MSZ: Masul Shear Zone; PL: Periadriatic Lineament; NGL: North Giudicarie Line. Grey striped area are ductile to brittle shear zones.

- Schema tettonico della catena Alpina (b) e del settore occidentale delle Alpi Orientali. SLG u.: unità di San Leonardo-Giovo; C.u.: unità di Punta Cervina; SV u.: unità di Scena-Verdins; MTS: Scaglia Tettonica di Marlengo; SNFZ: zona di taglio estensionale di Schneeberg (Monteneve); PSCBSZ: zona di shear di Pennes-Stilves-Corno Bianco; MSZ: zona di taglio di Rio Masul; PL: Lineamento Periadriatico; NGL: Linea delle Giudicarie Nord. In barrato grigio le zone di taglio fragili/duttili.

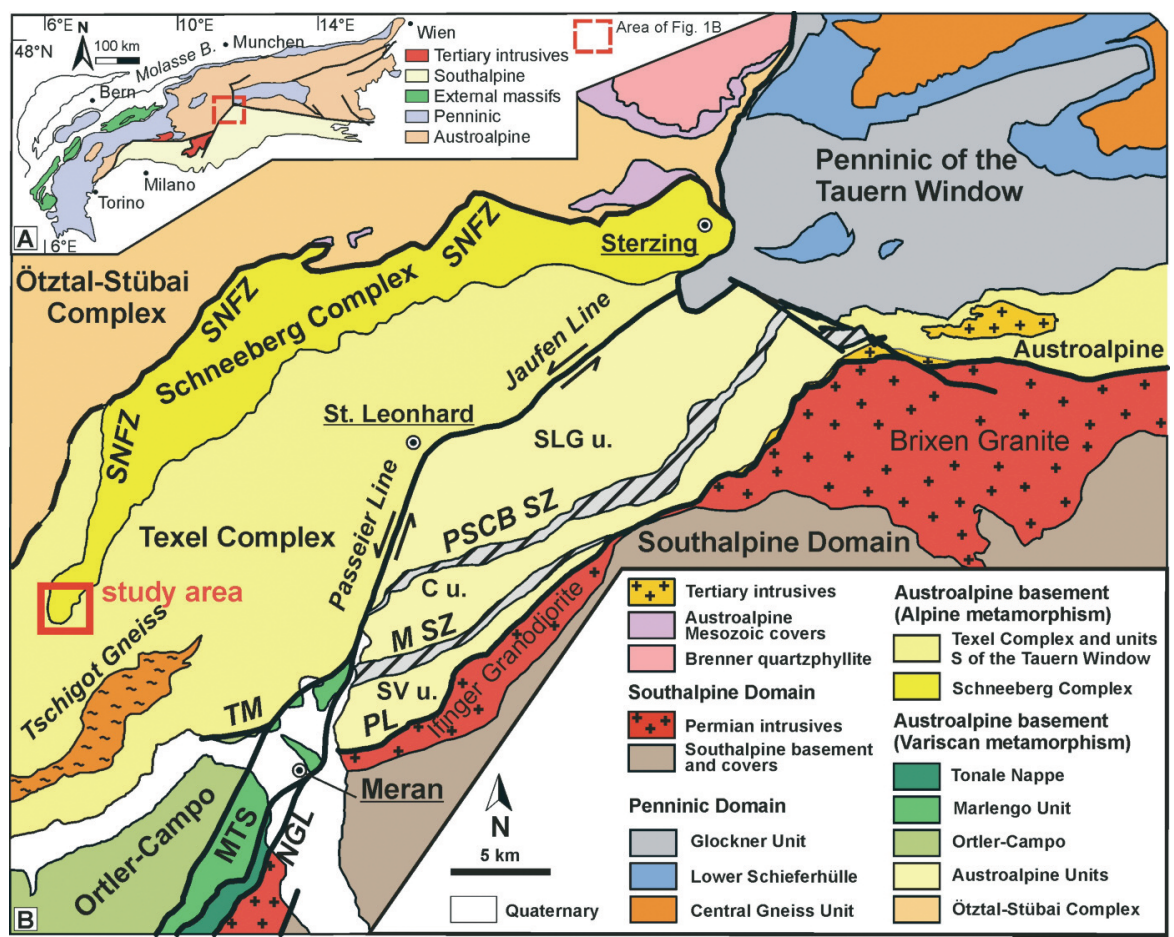

\section{GEOLOGICAL OUTLINE}

The Schneeberg and the Texel complexes belong to the basement units of the southern Austroalpine domain of the Eastern Alps (fig. 1a and 1b). In the area comprised between the Tauern Window to the west, the Engadine Window to the east and the North Giudicarie Fault to the south, the Austroalpine domain consists of a series of tectono-metamorphic units with distinct evolutions and age of metamorphism. In its southern portion it consists of several subunits comprised between the northern boundary of the Schneeberg Complex (Sölva et alii, 2005) and the Periadriatic Lineament to the south. The Tertiary Passeier and Jaufen lines (SPIESS, 1995; HoINKES et alii, 1999; Viola et alii, 2001) separate basement units with a pre-Alpine age of metamorphism to the east and south east and basement units with a dominant Alpine metamorphism to the west.

The fault system separating basement with Variscan metamorphism only and units with an Alpine overprint extends towards the east with the Deferrengen-AntholzVals lines (DAV) and represents, south and west of the Tauern Window, the Southern limit of Alpine Metamorphism (SAM; HoINKES et alii, 1999). The pre-Alpine basement east of the Passeier Line and south of the Jaufen Line is composed by several NE-SW trending units with different metamorphic imprint. From north to south they are: the San Leonhard-Jaufen (San Leonardo-Giovo) Unit, the Hirzer (Cervina) Unit and the Schenna-Verdins (Scena-Verdins) Unit. The San Leonhard basement chiefly consists of partly retrogressed garnet-staurolite gneisses, in part derived from a granitic protolith; this unit is bound to the north by the normal sinistral strikeslip Jaufen fault and to the south by the Pennes-StilvesCorno Bianco shear zone, a several hundreds of metrethick mylonitic-cataclastic shear zone with entrapped slices of unmetamorphosed Permo-Mesozoic sediments. Within the Pennes-Stilves-Corno Bianco shear zone a level of muscovite-biotite gneisses with peculiar rounded albite porphyroblasts of several centimetres in diameter occurs. The Hirzer Unit consists of garnet-kyanite-staurolite gneisses, with minor mica schists, amphibolites and granitic gneisses. The Hirzer basement is bound to the south by the Rio Masul shear zone, composed of muscovitic schists, banded gneisses, leucocratic gneisses and minor amphibolites, marbles and pegmatites, all of them displaying mylonitic fabric and locally interested by cataclastic fault zones. The Rio Masul shear zone turns from an WSW-ENE trend close to the Passeier Line to a SW$\mathrm{NE}$ direction moving eastwards, finally joining to the Periadriatic Lineament about $12 \mathrm{~km}$ east of the Passeier valley. The basement comprised between the Rio Masul shear zone to the north and the Periadriatic Lineament to the south is here referred as the Schenna-Verdins Unit. It is mainly composed of garnet-staurolite-sillimanite gneisses and mica schists with minor amphibolites, amphibolic gneisses and marbles. The presence of sillimanite replacing garnet and of K-feldspar within garnetbiotite gneisses, indicates the attainment of higher temperatures with respect to the Hirzer and the S. Leonhard units during the Variscan evolution.

The Austroalpine basement comprised between the Schneeberg Complex to the north, the Passeier and Jaufen lines to the east (VIOLA et alii, 2001) and the Vinschgau Shear Zone (ScHMID \& HAAS, 1989) to the south, is referred as the Texel Complex (TC) or Texel Group (Sölva et alii, 2005). The Texel Complex displays a polyorogenic metamorphic evolution with dominant amphibolite facies imprint of Alpine age (SPALLA, 1993; HoINKES et alii, 1999; Sölva et alii, 2005 and ref. incl.). The basement of the TC consists mainly of garnet-staurolite-kyanite mica schists and gneisses with minor amphibolites and marbles. Eclogites are preserved as small boudins within garnet amphibolites in several localities, e.g. Saltaus (HoInKES et alii, 1991; HABLER et alii, 2006), Moos (Poli, 1991) and Ulfas (Zanchetta, 2007). Addi- 


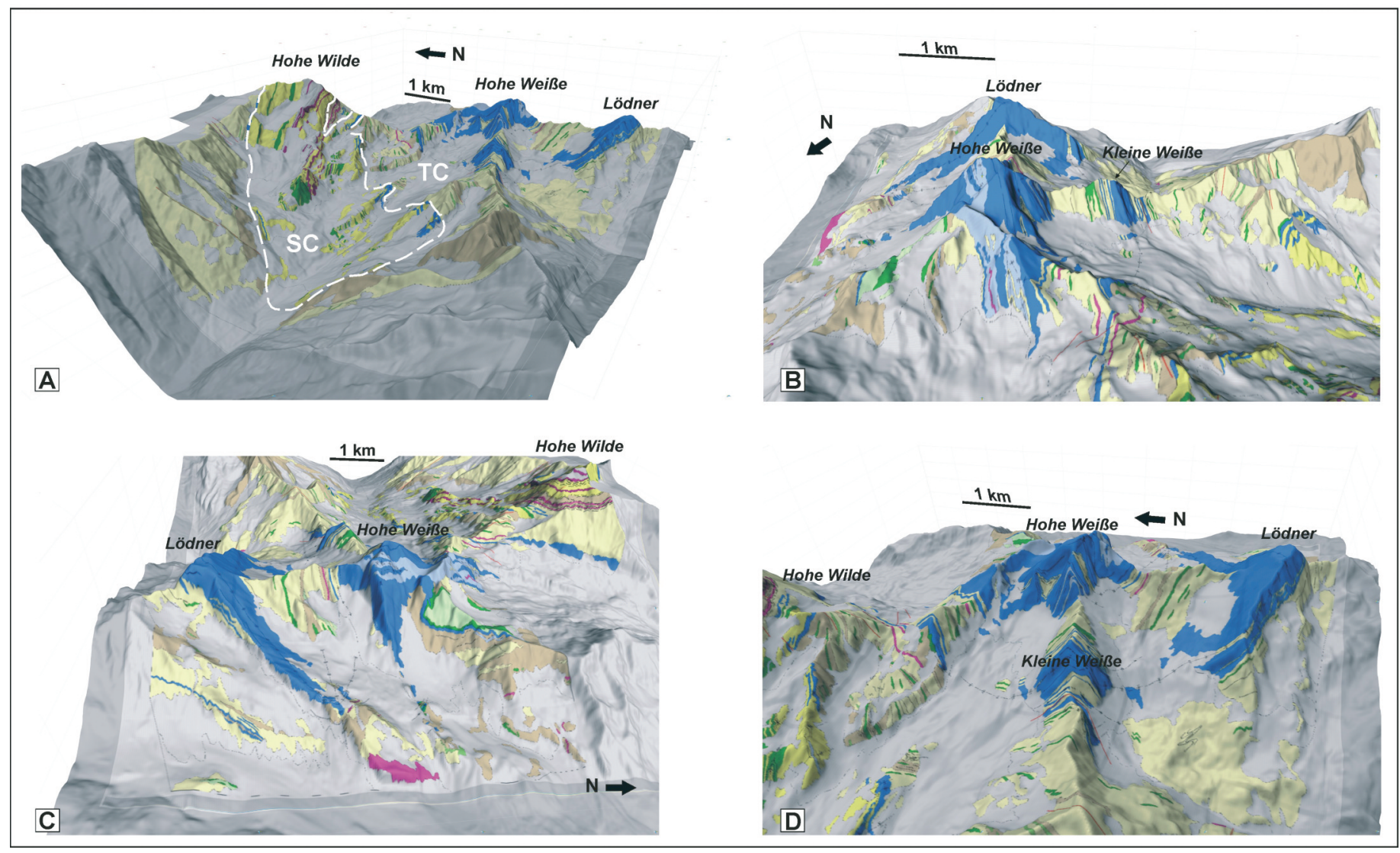

Fig. 2 - The geological map draped on 2.5 m resolution DTM (Digital Terrain Model, courtesy of Provinz Autonome Bozen): (a) View of the whole area with, in white, the inferred boundary between the Schneeberg (SC) and Texel (TC) complexes; $(b)$ The Lödner-Hohe Weiße structure highlighted by the marble layers, view from North; $(c)$ The upper Lazins valley, view from East; $(d)$ The upper Pfossen and Tel valleys, view from West.

- Carta geologica drappeggiata sul DTM con risoluzione a 2.5 m (Modello Digitale del Terreno, per concessione della Provincia Autonoma di Bolzano): (a) Vista dell'intera area con, in bianco, il limite interpretato fra il Complesso di Schneeberg (SC) e il Complesso di Texel (TC); (b) La struttura Cima Fiammante-Cima Bianca Grande evidenziata dall'andamento dei livelli di marmi, vista da Nord; (c) La parte superiore della valle di Lazins, vista da Est; (d) La parte superiore delle valli di Fosse e Tel, vista da Ovest.

tionally, garnet amphibolites containing diopside+plagioclase or amphibole+plagioclase symplectites are widespread throughout the complex. HoInkes et alii (1991) indicate minimum pressures of 1.1-1.2 $\mathrm{GPa}$ at $500-550{ }^{\circ} \mathrm{C}$; higher temperatures $\left(700{ }^{\circ} \mathrm{C}\right)$ were suggested by POLI (1991). Spalla (1993) reported a high pressure event also within the metapelites of the Texel Complex in the upper Spronser valley, where pressure of 1.1-1.2 GPa and temperature of $640-680{ }^{\circ} \mathrm{C}$ are suggested for the syn- $\mathrm{D}_{1}$ metamorphic event. Recent U-Pb data on zircon (ZANCHETTA et alii, 2007) and garnet Sm-Nd data (HABLER et alii, 2006) constrain the eclogite facies event at $85 \pm 4 \mathrm{Ma}$ and $84 \pm 5$, respectively.

The Schneeberg Complex includes quartz-rich mica schists with centimetric garnets, garnet and carbonate amphibolites, calc-schists, graphite-rich schists, amphibolic schists with centimetric hornblende crystals ( Garbenschiefer» Auct.), marbles levels several metres thick and garnet-bearing quartzites. The transition between the Texel and the Schneeberg Complexes is marked by the so called "Laas Serie», due to its similarity to the rocks serie cropping out north of Lasa, in the Vinschgau valley. The Laas Serie (HoINkEs et alii, 1987) is made of massive marble layers, up to 150-200 metres thick, garnet-staurolite mica schists, paragneisses and minor amphibolites and quartzites. The rocks of the Laas Serie have been pre- viously alternatively attributed to the Schneeberg Complex or the Texel Complex.

The SC has been traditionally considered as a monometamorphic unit, derived from an autochthonous Paleozoic sedimentary sequence of the Ötztal-Stübai domain, that experienced Alpine metamorphism only (HoINKES et alii, 1987), with peak metamorphic conditions close to the eclogite-amphibolite facies boundary at 0.8-1.0 GPa and 550-600 ${ }^{\circ} \mathrm{C}$ (KONZETT \& HoINKES, 1996).

\section{METHODS AND GEOLOGIC MAPPING CRITERIA}

The study area has been mapped at a 1:5.000 scale. The results of the field work are summarized in the attached geological-structural map at the 1:10000 scale (plate 1) and in the 3D representation of the study area in fig. 2. Structural analysis at the meso-scale has been performed to unravel the tectonic sequence of events (TURNER \& WEISS, 1963; HoBBS et alii, 1976; RAMSAY \& HUBER, 1987). In complex areas of an orogen axial belt, where large scale deformation took place, finite strain distribution can result extremely heterogeneous and it is not always possible to determine one single sense of displacement and the prevailing deformation mechanism at local scale, as a result of polyphase tectonic imprints. 
Therefore the reconstruction of the structural pattern of the area and of the relative succession of the different deformation events, requires the individuation of different structural domains where the signatures of prevailing progressive shortening (pure shear) or prevailing progressive shearing (simple shear) are dominant. Finite strain partitioning in a poly-deformed area may result in domains where the oldest deformation structures occur and domains where the successive transpositions due to the late deformation events have completely obliterated the imprints of earlier stages; the individuation of such domains is the key-step in the reconstruction of the structural evolution.

Lithologies have been classified and consequently mapped using macroscopic mineralogical and structural characters, with no use of differentiations based on microscopic features.

\section{LITHOLOGY}

In the following paragraphs a field description of the mapped lithogies is provided, comprehensive of all the characters directly observable in the field. A brief description of the relations between mineral growth and fabric elements as determined through microstructural analysis is given for the metapelites of the Schneeberg and Texel complexes.

\section{TEXel Complex}

In the study area the polymetamorphic basement of the Texel Complex consists of mica schists and paragneiss, with minor amphibolites, amphibole gneisses, quartzites, calc-schists and marbles. The lithologic association of interbedded marbles, calc-schists and mica schists was referred as the "Laas Serie» or "Laaser Serie» since the work of HAMMER (1912) due to its similarity to the Ortler-Campo basement in the area of Laas (Vinschgau valley). In the literature marbles and mica schists of the Laas Serie have been usually attributed to the SC, mainly on the base of the presence of marbles and calcschists that represent common lithologies in the external part of the SC, while they are rare in the TC. In this work we chose to attribute the rocks of the Laas Serie Auct. to the TC as their petrographic features, particularly in metapelites and metapsammites, and recorded structural evolution, closely match the ones of the Texel basement and present important differences with the SC ones. Moreover, in the eastern part of the study area, the TC-SC boundary is clearly marked by a ductile shear zone, developed at amphibolite facies conditions, that separates mica schists and marbles of the TC from the peculiar lithological assemblage of the external part of the SC.

\section{Mica schists}

Mica schists are medium to fine grained rocks, with garnet and biotite phorpyroblasts embedded in a sericitic matrix. Garnet, biotite, white mica, plagioclase, quartz, tourmaline and rare staurolite are well recognizable in the field. The mineralogy, determined in thin sections, is: white mica, biotite, quartz, plagioclase, garnet, staurolite, kyanite, chlorite and accessory phases such as tourmaline, apatite, rutile, ilmenite and zircon. The mica schists display a S-tectonitic fabric, with a pervasive axial plane foliation, marked by the shape preferred orientation of white mica and biotite. Refolded centimetre-thick quartz layers and lenses are quite common, attaining in some outcrops $15 \%$ of the total volume of the rock. Within $\mathrm{D}_{3}$ fold hinge zones a strong crenulation of the $S_{2}$ foliation occurs, associated with a well developed crenulation lineation in phyllosilicate-rich layers. Garnet forms euhedral and sub-euhedral phorpyroblasts usually with diameter of a few millimetres. Close to the SC-TC boundary a generation of ellipsoidal garnets is found in the Texel rocks; in thin sections these garnets result to be formed by agglomerates of small, often submillimetric, rounded garnet crystals (SPIESS et alii, 2001). Within $\mathrm{D}_{4}$ decimetre-thick shear zones and kink bands, garnets are almost completely replaced by chlorite. Biotite porphyroblasts reach 2-3 $\mathrm{mm}$ in size. Tourmaline crystals are quite rare; they are $7-8 \mathrm{~mm}$ in length, always laying on the $S_{2}$ plane and are frequently boudinaged; rare small sub-millimetric garnets are included within tourmaline porphyroblasts.

The relationships between minerals growth and deformation events have been reconstructed by a microstructural study of thin sections. As previously discussed, the most pervasive fabric element at the microand mesoscale is the $S_{2}$ axial plane foliation marked by $\mathrm{Bt}_{\mathrm{II}}$ and $\mathrm{Wm}_{\mathrm{II}}$ (mineral abbreviation as in KRETZ, 1983, except for Wm: white mica). Kyanite and staurolite are seen to be stable during all the $\mathrm{D}_{2}$ deformation event with Ky growing early- to syn- $S_{2}$, whereas $S t$ was observed to be mainly syn- to post-S $S_{2}$. Garnet porphyroblasts display a polyphase growth, with an inner, inclusion-rich, pre- $\mathrm{D}_{2}$ core $\left(\mathrm{Grt}_{\mathrm{I}}\right)$ surrounded by an overgrowth $\operatorname{rim}\left(\mathrm{Grt}_{\mathrm{II}}\right)$ developed syn-kinematically to $S_{2}$.

Typical mica schists outcrops occur in the Lazins valley and along the southern slope of the Pfossen valley.

\section{Paragneisses}

The two mica paragneisses are the most widespread lithology in the TC. The paragneisses are medium to fine grained, usually characterised by a banded texture, due to a mineralogical layering formed by alternating quartzfeldspar and mica-rich layers. Millimetric porphyroblasts of garnet and tourmaline are quite common, whereas staurolite is rare and often recognizable only in thin sections. Chlorite replaces biotite and garnet porphyroblasts whitin post- $\mathrm{D}_{3}$ shear zones.

The mineralogy is made of quartz, plagioclase, biotite, white mica, garnet, staurolite, chlorite and minor apatite, rutile, ilmenite and zircon. Small crystals of kyanite occur in a few samples. The relationships between fabric elements and mineral growth are similar to those described for the mica schists, with garnet displaying a poly-phase growth during two main stages (pre- $\mathrm{D}_{2}$ and $s y n-\mathrm{D}_{2}$ ). Kyanite and staurolite are syn- $\mathrm{D}_{2}$, except for a couple of sample where pre- $\mathrm{D}_{2}$ kyanite crystals were observed. White mica and biotite mainly grow syn-kinematically during $\mathrm{D}_{2}\left(\mathrm{Wm}_{\mathrm{II}}\right.$ and $\left.\mathrm{Bt}_{\mathrm{II}}\right)$. $\mathrm{Wm}_{\mathrm{I}}$ and $\mathrm{Bt}_{\mathrm{I}}$ crystals are commonly observed as porphyroclasts within $S_{2}$, with (001) cleavage traces at a high angle with $S_{2}$. No pervasive foliation is associated to the $\mathrm{D}_{3}$ fold system; only in some cases (upper Lazins valley) a poorly defined cleavage derived from the de-crenulation of $\mathrm{S}_{2}$ (stage 3 to 4 of Bell \& RubenACH, 1983; BeLl, 1986) was observed, defined by newly formed $\mathrm{Wm}_{\mathrm{III}}$ and $\mathrm{Bt}_{\mathrm{III}}$. 

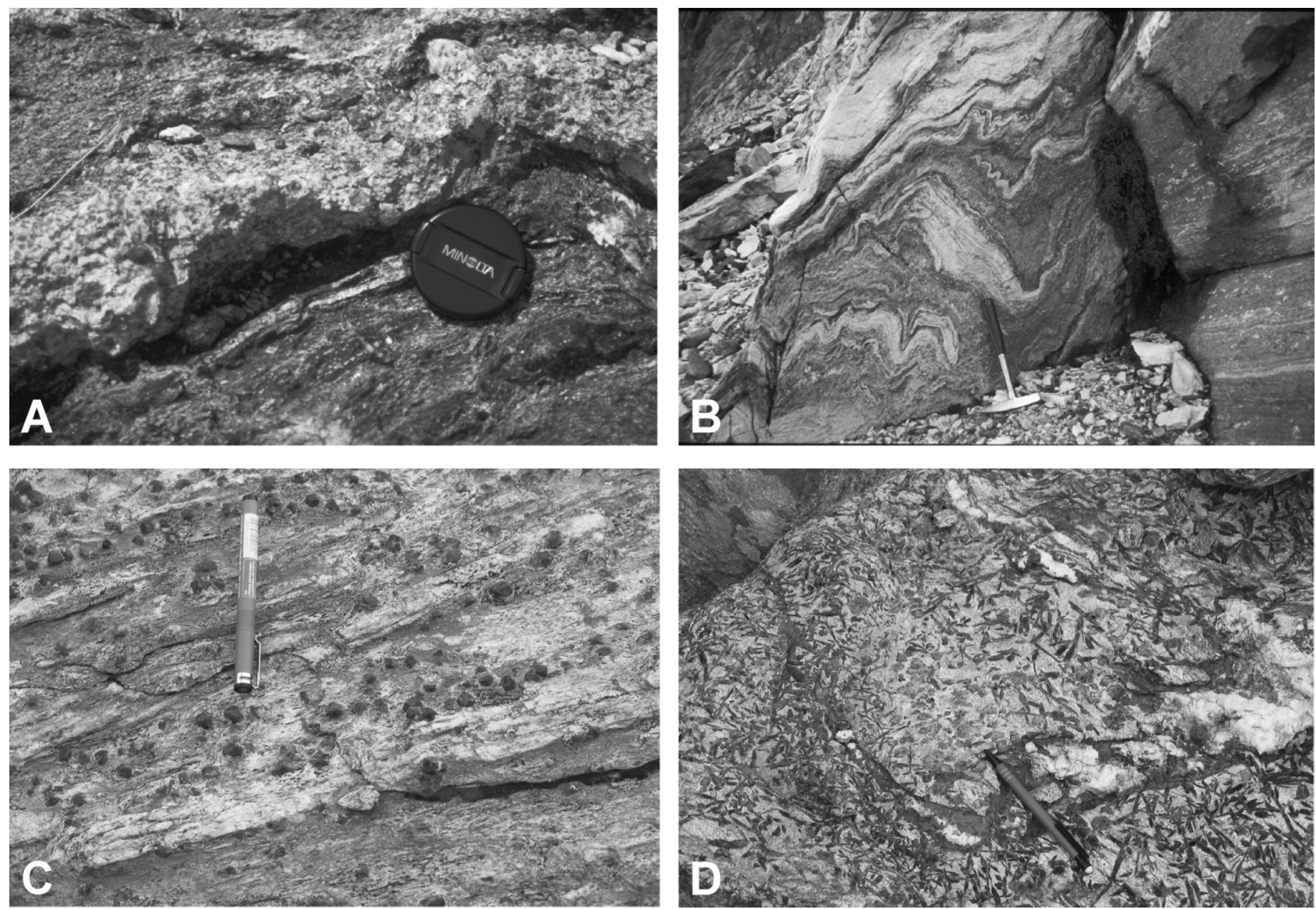

Fig. 3 - Example of common lithologies cropping out in the study area: (a) Amphibolic gneiss of the Texel Complex with typical plagioclase-garnet layers, upper Lazins valley; $(b)$ Calc-schists of the Texel Complex interested by $\mathrm{D}_{3}$ folds, with interbedded carbonates and phyllosilicates-rich layers, Grafen Peak; $(c)$ Schneeberg mica schists containing centimetre-sized garnet porphyroblasts with idiomorphic habit; $(d)$ Post-D $_{2}$ growth of garnet and amphibole porphyroblasts at the contact between mica schists and carbonate amphibolites of the Schneeberg Complex. - Alcuni esempi dei principali litotipi affioranti nell'area di studio: (a) Gneiss anfibolici del Complesso di Texel con caratteristici livelli a soli plagioclasio e granato, alta valle di Lazins; (b) Calcescisti del Complesso di Texel con livelli a carbonati e livelli ricchi in fillosilicati, l'alternanza rende ben visibili le pieghe $D_{3}$ che interessano l'affioramento, Cima Grava; (c) Micascisti del Complesso di Schneeberg con porfiroblasti centimetrici di granato avente abito idiomorfo; (d) Crescita statica post- $D_{2}$ di granato ed anfibolo al contatto fra $i$ micascisti e le anfiboliti a granato del Complesso di Schneeberg.

\section{Quartzites}

Quartzites occur as some metres thick layers, mainly interbedded with mica schists. Small amounts of submillimetric white mica, together with chlorite, plagioclase and oxides, are usually present. The quartzites display a S-tectonitic fabric with a locally well developed SPO (shape preferred orientation) of quartz crystals and isoorientation of white mica along the main foliation planes.

\section{Amphibolites and garnet amphibolites}

The amphibolites are medium to fine grained rocks with a typical banded texture due to the mineralogical layering consisting in alternating amphibole- and plagioclase-rich bands. The mineralogy consist of: amphibole, plagioclase, clinozoisite/zoisite, biotite, titanite, rutile, apatite and rare zircon. Garnet porphyroblasts reaching $10 \mathrm{~mm}$ in diameter are present in some levels. Within the amphibole-rich levels the $\mathrm{S}_{2}$ regional foliation is marked by a preferred orientation of amphibole and biotite; the $S_{2}$ foliation is always parallel to the banding except in some boudins where a small angle is observed between the mineralogical layering of amphibolites and the external $\mathrm{S}_{2}$ of mica schists or paragneisses wrapping around the boudins, suggesting that foliation and mineralogical layering within amphibolites levels possibly represents a re-orientation of pre- $\mathrm{D}_{2}$ structures. Garnet amphibolites show the same textural characters of the previous rock types. A metasomatic corona made of plagioclase and garnet marks the contact between the amphibolites and the surrounding paragneisses and mica schists.

\section{Amphibole schists}

The amphibole schists crop out NE of the Grafen Peak, interbedded with calc-schists, mica schists and garnet amphibolites. The mineralogical association includes amphibole, plagioclase, garnet, biotite, quartz and minor amounts of white mica and rutile. The rock is medium- to fine-grained with porphyroblasts of amphibole and garnet reaching size of some millimetres. 5 to 10 centimetrethick plagioclase and garnet layers locally occur (fig. 3a). 
The main foliation $\left(\mathrm{S}_{2}\right)$ is marked by the preferred orientation of amphibole and biotite.

\section{Calc-schists}

Calc-schists and marbles are characteristic of the Laas Serie Auct. The calc-schists crop out in some decimetreto several tens of metre-thick layers, alternated with marbles, mica schists and amphibolites. They constitute most of the Grafen Peak in the NE part of the area and are interbedded with the marble layers of the Höhe Weiße. The calc-schists are characterized by alternating calciterich and mica-rich layers (fig. 3b); within carbonate levels epidote and diopside are common accessory minerals, while plagioclase, chlorite, tremolitic amphibole and quartz are present in the mica-rich layers.

On the south face of Grafen peak, within the calcschists, some metric boudins of peculiar calcsilicate rocks occur. These rocks are coarse grained and composed of diopside, titanite, quartz, amphibole and garnet. Single idioblastic crystal of titanite with a barrel-shaped crystallographic habit reach 5-6 cm in length.

\section{Marbles}

Several hundreds of metre-thick marble layers form the summits of the Höhe Weiße, Kleine Weiße and Lödner peaks. The marbles are mainly calcitic; some decimetre-thick, light pink coloured, dolomitic layers occur on the SE face of the Lödner Peak in the upper Lazins valley. White mica, quartz, chlorite and epidote are common accessory mineralogical phases.

\section{SCHNEEBERG COMPLEX}

The Schneeberg Complex or «Schneeberger Geisteinzug» (SANDER, 1921), was traditionally distinguished from the surrounding Austroalpine basement for its peculiar lithological assemblages, especially in the the so called "Heterogeneous Marginal Zone» or "Bunte Serie» (MAURACHER, 1981), where interbedded coarse grained amphibolites, mica schists with gigantic garnets, calc-schists, marbles and garnet quartzites occur. The central part of the complex is instead made of sericitic mica schists (the «Monotonous Serie» Auct.), locally resembling phyllites with a dark grey colour. Most of the lithologies cropping out in the study area belong to the external part of the SC.

\section{Mica schists}

The mica schists belonging to the SC are medium to coarse grained, with centimetric porphyroblasts of garnet, biotite and, locally, amphibole. The mineralogy consists of white mica, biotite, quartz, plagioclase, garnet, staurolite, kyanite, epidote/allanite, rutile, graphite, \pm titanite, \pm amphibole, \pm calcite, \pm apatite. The fabric is S-tectonitic, with a pervasive foliation $\left(\mathrm{S}_{2}\right)$ marked by biotite and white mica. The centimetre-sized (over $2 \mathrm{~cm}$ in diameter) porphyroblasts of garnet are usually euhedral, often showing a rombododecahedric crystallographic habit. Garnets are abundant, often constituting the $7-8 \%$ in volume of the whole rock. Within 2-3 $\mathrm{m}$ from the contact between the mica schists and the garnet amphibolite boudins, centimetric, up to $10 \mathrm{~cm}$ long, amphibole porphyroblasts grow post-kinematically with respect to the main $\left(\mathrm{S}_{2}\right)$ foliation (fig. $3 \mathrm{~b}$ and fig. 3c). The presence of amphiboles within the mica schists is often accompanied by calcite and small crystals of titanite, sometimes replaced by epidote + rutile + quartz aggregates. The amphibole- and garnet-rich mica schists are known in the literature as "Garbenschiefer» or "Horneblendegarbenschiefer». Commonly biotite $\left(\mathrm{Bt}_{\mathrm{IV}}\right)$ is seen to replace former amphibole porphyroblasts.

White mica $\left(\mathrm{Wm}_{\mathrm{I}}\right)$ and $\mathrm{Bt}\left(\mathrm{Bt}_{\mathrm{I}}\right)$ porphyroclasts are preserved as relics generally oriented parallel to $S_{2}$ but with (001) cleavage planes at high a angle with respect to the foliation. Undulose extinction, kink bands and dissolved rims are common features both for $\mathrm{Wm}_{\mathrm{I}}$ and $\mathrm{Bt}_{\mathrm{I}}$. Submillimetric white micas are also present as rare inclusions within pre- $\mathrm{D}_{2}$ garnet cores, together with allanite, rutile, quartz and apatite. A second generation of white mica $\left(\mathrm{Wm}_{\mathrm{II}}\right)$ and biotite $\left(\mathrm{Bt}_{\mathrm{II}}\right)$ defines the $\mathrm{S}_{2}$ foliation. A spaced axial plane foliation $\left(\mathrm{S}_{3}\right)$ associated to $\mathrm{D}_{3}$ folds is locally developed and its growth is accompained by the de-crenulation of the $S_{2}$ foliation (stage 3-4 of BELL \& RUBENACH, 1983; BELL, 1986). The $S_{3}$ cleavage is mainly defined by the preferred orientation of sericitic white mica $\left(\mathrm{Wm}_{\mathrm{III}}\right)$, in a few samples associated with a third generation of biotite, $\mathrm{Bt}_{\mathrm{III}}$. Staurolite and kyanite grow syn-kinematically with $\mathrm{S}_{2}$ and usually display a shape preferred orientation parallel to the $S_{2}$ foliation. Inclusion trails of quartz, ilmenite and rare white mica, continuous with the external $S_{2}$ are a common feature in staurolite porphyroblasts, whereas kyanite is mainly inclusion-free. Garnet porphyroblasts show a complex growth history with at least three distinct stages. Almost inclusion-free garnet core $\left(\mathrm{Grt}_{\mathrm{I}}\right)$ with irregular boundaries have been found in a few samples. Such cores are surrounded by a portion $\left(\mathrm{Grt}_{\mathrm{II}}\right)$, usually representing more than $60 \%$ in volume of the porphyroblasts, that is rich in inclusions of rutile, quartz and graphite, with minor white mica $\left(\mathrm{Wm}_{\mathrm{I}}\right)$ and allanite. The inclusions define an internal foliation, tentatively assumed to correspond to $S_{1}$, at a high angle with respect to the external $S_{2}$.

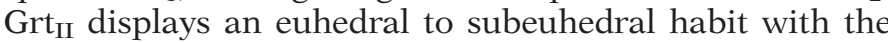
outer rim highlighted by concentration of randomly oriented rutile, quartz and graphite. An outer rim $\left(\mathrm{Grt}_{\mathrm{III}}\right)$, almost inclusion-free, is often present. The relations between the $S_{2}$ foliation and the Grt ${ }_{I I I}$ rim of garnet porphyroblasts suggests a late- to post- $\mathrm{D}_{2}$ growth of Grt $\mathrm{IIII}_{\text {. }}$.

The Schneeberg mica schists crop out widely on the northern slope of the Pfossen valley, while the garnet- and amphibole-rich ones are visible along the path running at the bottom of the valley, between $2300 \mathrm{~m}$ and $2450 \mathrm{~m}$.

\section{Graphitic schists}

Graphite rich schists are common in the Bunte Serie or "Heterogeneous Marginal Zone» of the SC (MAURACHER, 1981). They are composed mainly of quartz, plagioclase, white mica and biotite, garnets are rare. Finely dispersed submillimetric clusters of graphite attribute a dark grey colour to the rock. The graphitic schists crop out in several metres thick layers in Pian del Catino, south west of the Höhe Wilde.

\section{Garnet quartzites}

Quartzites levels are interbedded with the Schneeberg mica schists and the graphitic schists. Small amounts of submillimetric white mica, together with chlorite, plagioclase 

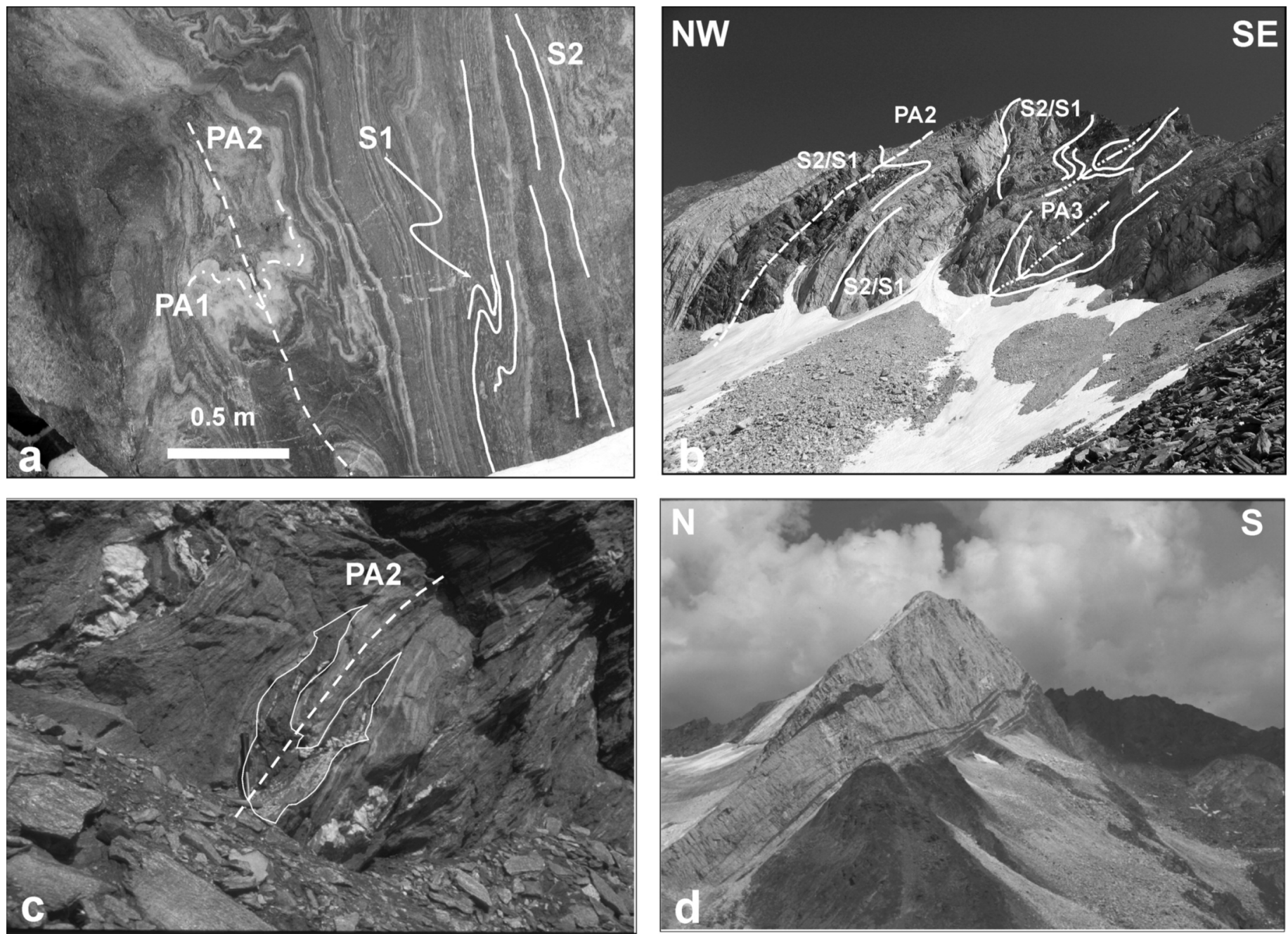

Fig. 4 - (a) Relict $\mathrm{D}_{1}$ folds and $\mathrm{S}_{1}$ axial plane foliation within the main foliation $\mathrm{S}_{2}$. $\mathrm{D}_{1}$ relics are well recognizable in mica-poor lithologies and calcschists, like in this case; (b) SW face of the Hohe Weiße. $\mathrm{D}_{1}$ and $\mathrm{D}_{2}$ structures are responsible for the lithological layering, later refolded by SE-vergent $\mathrm{D}_{3}$ folds; (c) An amphibolite boudin interested by a $\mathrm{D}_{2}$ fold; $(d)$ Complex $\mathrm{D}_{1}-\mathrm{D}_{2}$ structures on the SW face of the Lodner Peak. The mica schists layers, several metres thick, interbedded within the massive marbles underline the $\mathrm{D}_{1}$ folds refolded during the $\mathrm{D}_{2}$ event.

- (a) Pieghe $D_{1}$ e foliazione $S_{1}$ relitte preservate all'interno della foliazione principale $S_{2}$; (b) Parete $S W$ della Cima Bianca Grande. Le strutture $D_{1}$ e $\mathrm{D}_{2}$ sono responsabili della ristrutturazione del layering litologico, successivamente ripiegato dal sistema di pieghe $D_{3}$ vergente verso SE; (c) Boudin di anfiboliti deformato da una piega $D_{2}$; (d) Complesse figure di interferenza $D_{1}-D_{2}$ sulla parete $S W$ della Cima Fiammante. I livelli di micascisti, spessi alcuni metri, intercalati ai massivi livelli di marmo individuano i relitti delle strutture $D_{1}$.

and oxides, are usually present. The main characteristic is the presence of euhedral garnet porphyroblasts up to 10-15 mm in diameter. The garnet quartzites crop out just below the summit of the Höhe Wilde and in the Pian del Catino area.

\section{Amphibolites and garnet amphibolites}

The amphibolites of the SC differ form the TC ones for being usually coarse grained, with garnet and amphibole porphyroblasts reaching size up to $2-3 \mathrm{~cm}$ for garnet and up to $10 \mathrm{~cm}$ for amphibole. Another difference is the presence of thin ( 1 to $20 \mathrm{~mm}$ thick) carbonatic layers alternating with amphibole- and plagioclase-rich ones. The mineralogy of the amphibolites is constituted by: amphibole, plagioclase, biotite, titanite, \pm garnet, \pm epidote, \pm rutile, \pm white mica.

\section{Marbles and Calc-schists}

Some metres thick marbles layers define the outer rim of the SC. The marbles are almost pure with only minor white mica and quartz. Calc-schists occur in small lenses and several centimetres to 1-2 metre-thick layers within garnet amphibolites and mica schists. Within calc-schists white mica, epidote, biotite and chlorite are present and often mesoscopically recognizable in the field.

\section{FOLD, CLEAVAGE AND FAULT ANALYSES IN THE STUDY AREA}

The SC is interpreted as a Paleozoic sedimentary succession with an Alpine tectono-metamorphic imprint (HoINKEs et alii, 1987). Several radiometric data support this interpretation and constrain the age of the Eo-Alpine metamorphic event in the SC rocks around $85 \mathrm{Ma}$ (KonZETT \& HoINKES, 1996). However the structural relationship between the ÖSC, the TC and the SC, in the upper Pfelders and Pfossen valleys are still unclear. Eastward of the studied area GREGNANIN et alii (1995) proposed the existence of a tectonic structure, the Zermaid- 


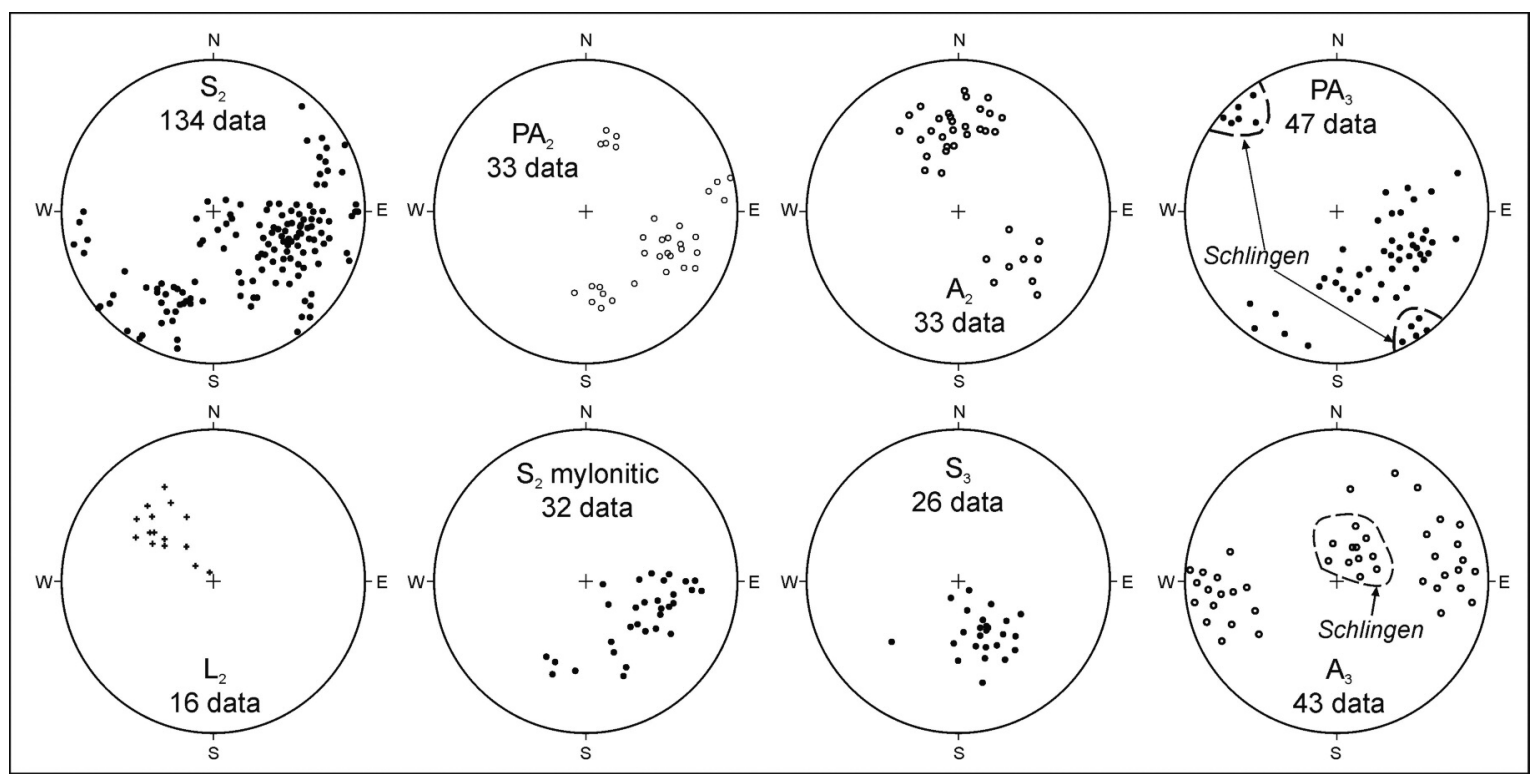

Fig. 5 - Equiareal stereographic projection of structural data, lower emisphere. Axial planes and foliations are projected as poles to planes. Data related to the «Schlingen» $\mathrm{D}_{3}$ folds with steep axes of the SW termination of the Schneeberg Complex are highlighted. Structural data are referred to the whole study area.

- Proiezioni stereografiche equiareali, emisfero inferiore, dei dati giaciturali dei principali elementi strutturali. Le foliazioni e piani assiali di pieghe sono rappresentati come poli ai piani. I dati relativi alle pieghe $D_{3}$ a «Schlingen» caratteristiche della terminazione SW del Complesso di Schneeberg sono evidenziati. I dati strutturali si riferiscono all'intera area cartografata.

Weissen line, along which the SC overthrusted the TC basement with a prevalent "top-to-S-SE» direction. West of Moos the Zermaid-Weissen line vanishes and no evident tectonic lineaments are present at the SC-TC boundary. A recent work (SölVA et alii, 2005) suggests the existence of a thick normal fault zone, the Schneeberg Normal Fault Zone (SNFZ), which was active from pressure-dominated amphibolite facies (KonZETT \& HoINKES, 1996) to brittle conditions. Along such a fault zone, affecting the whole of the SC, the eclogite facies rocks cropping out in the Texelgruppe have been exhumed with a «top-to-WNW» shear sense, that have been inferred on the base of the dominant asymmetry of structures (asymmetric clasts, flanking folds).

\section{FOLD SYSTEMS AND CLEAVAGE ANALYSIS}

At least four distinctive ductile deformation phases have been recognized. Three of these phases $\left(D_{1}, D_{2}\right.$ and $D_{3}$ ) are associated with metamorphism.

$\boldsymbol{D}_{\boldsymbol{1}}$ - The $\mathrm{D}_{1}$ structures, within the Texel Complex, occur as isoclinal folds up to decimetric in size or as a relic foliation preserved in the $\mathrm{D}_{2}$ fold hinge zones.

The $\mathrm{D}_{1}$ structures have been almost completely dissected and passively rotated by the subsequent deformation phases, without preservation of the original orientation. At the outcrop scale the transposition of $\mathrm{D}_{1}$ structures by $\mathrm{D}_{2}$ is visible in the alternating silicate-rich and carbonate-rich layers in calc-schists (fig. 4a).

Kilometre scale structures produced by the interference pattern of $D_{1}$ and $D_{2}$ folds are exposed near the summit of the Höhe Weiße and on its SE face in the upper Lazins valley. The interference pattern between $D_{1}$ and $D_{2}$ folds is of type 3 of RAMSAY \& HUBER (1987), with almost parallel $\mathrm{D}_{1}-\mathrm{D}_{2}$ axes and axial planes at high angles. $\mathrm{D}_{1}$ folds relics are also recognized on the SW face of the Löd- ner Peak, where they are marked by thin mica schists layers interbedded within massive marbles (fig. $4 d$ ). The $S_{1}$ foliation, developed at amphibolite facies conditions, is marked by biotite and muscovite in mica schists, amphibole and biotite in mafic rocks, epidote and muscovite in calc-schists. Relics of $S_{1}$ are best preserved in mica poor lithologies, such quarzites, amphibolites and calc-schists, whereas they were not recognized, except at the scale of thin sections, in mica schists. Amphibolite boudins are locally deformed by $\mathrm{D}_{2}$ folds, suggesting that boudinage is probably due to $\mathrm{D}_{1}$ deformation event (fig. $4 \mathrm{c}$ ).

In the basement rocks of the SC the pre- $\mathrm{D}_{2}$ structures are hardly recognizable as the continuous $S_{2}$ foliation, locally mylonitic, tends to obliterate all pre-existing structures. Relics of a $S_{1}$ foliation are rarely preserved within $D_{2}$-folds hinge zone and rootless $S_{1}$ folds have been seldom observed within quartz-rich mica schist layers.

Along $\mathrm{D}_{2}$ folds limbs the $\mathrm{S}_{2}$ foliation in mica schists forms a small angle with lithological boundaries $\left(\mathrm{S}_{\mathrm{L}}\right)$ of marble and quartzite levels. The continuity of the litostratigraphic boundaries is often interrupted as an effect of superposed $\mathrm{D}_{1}$ and $\mathrm{D}_{2}$ deformation structures.

From field analysis of fold systems and cleavages, a direct correlation between the $\mathrm{S}_{1}$ relic structures of the TC and SC is not possible, and the $\mathrm{D}_{1}$ deformational phase could be diachronous in the two basement units.

$\boldsymbol{D}_{\mathbf{2}}$ - The $\mathrm{D}_{2}$ deformation phase is responsible for the development of isoclinal folds from outcrop to regional scale. An axial plane foliation, namely $\mathrm{S}_{2}$, developed at amphibolite facies conditions, is the most pervasive fabric at the meso and micro scale. $\mathrm{S}_{2}$ has a prevalent WNW dip direction with dip angles ranging from $30^{\circ}$ to $90^{\circ}$. $\mathrm{D}_{2}$ fold axes $\left(\mathrm{A}_{2}\right)$ show a trend between NW and NNE with highly variable plunges. The scattering of $S_{2}$ and $A_{2}$ attitudes is related to the reorientation effect of subsequent deformation phases, mainly to $\mathrm{D}_{3}$ (fig. 5). 

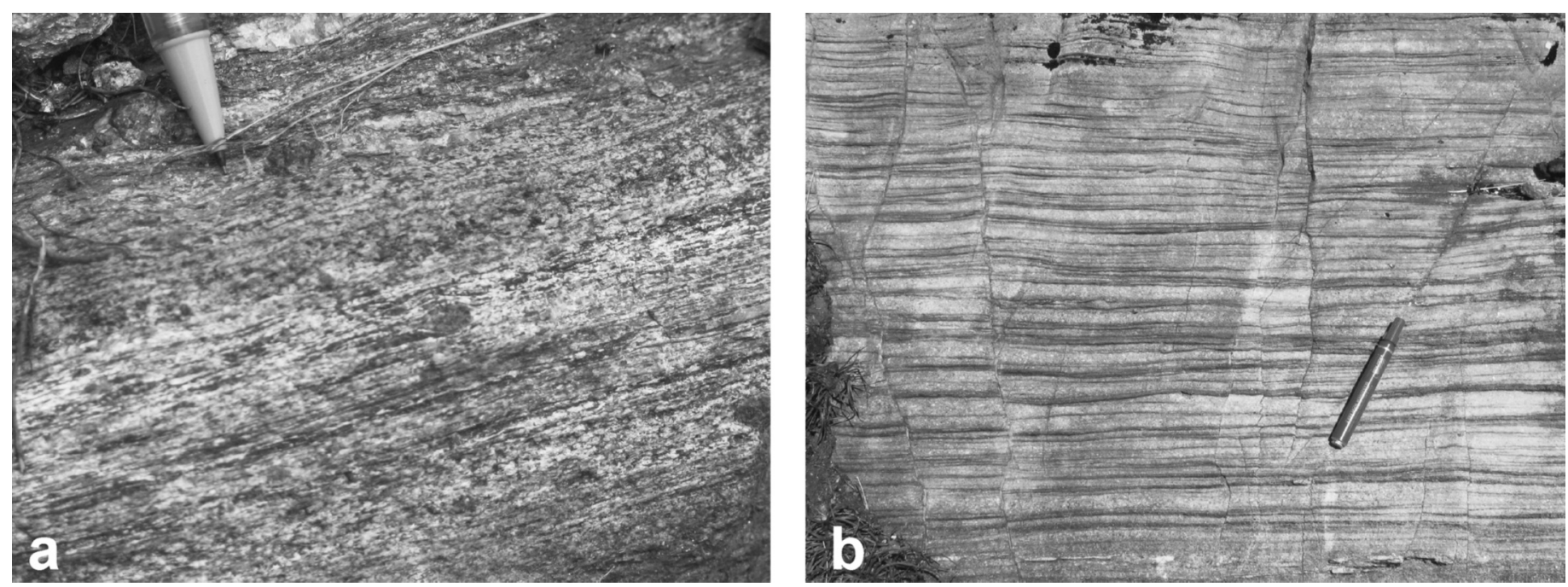

Fig. 6 - (a) Garnet-staurolite paragneiss of the Texel Complex with a mylonitic fabric. Shear zone close to the Texel-Schneeberg boundary, SW of the Hohe Wilde; $(b)$ Mylonitic marbles. The thin black layers are mainly formed by white mica and quartz. NW of the Stettiner Hütte, along the path to the Hohe Wilde.

- (a) Paragneiss a granato e staurolite del Complesso di Texel con fabric milonitico, zona di taglio in prossimità del limite Texel-Schneeberg, a SW dell'Altissima; (b) Marmi a silicati con foliazione milonitica. I livelletti neri sono formati prevalentemente da mica bianca e quarzo. NW del Rifugio Petrarca, lungo il sentiero per l'Altissima.

The lithological layering, outside fold hinge zones, is parallel to $\mathrm{S}_{2}$ and it is thought to have developed in response to the superposition of $\mathrm{D}_{1}$ and $\mathrm{D}_{2}$ deformational events.

Several mega scale structures belong to the $\mathrm{D}_{2}$ fold systems, the most evident is the kilometre scale $\mathrm{D}_{2}$ synform traced by the marbles of the Kleine Weiße and Lödner Peak (ZANCHI et alii, 2009). Other megascopic $\mathrm{D}_{2}$ structures are well visible on the SW and NW faces of the Höhe Weiße where interbedded mica schists and calcschists form the core of an approximatively N-S trending antiform, later refolded during the $\mathrm{D}_{3}$ event.

The $S_{2}$ foliation within the TC is marked by the preferred orientation of white mica and biotite in mica schists and paragneisses, biotite and amphibole in metabasites, epidote, white mica and rare diopside in calc-schists. The lithological layering $\left(\mathrm{S}_{\mathrm{L}}\right)$ in massive amphibolites, paragneisses and calc-schists is parallel to the $S_{2}$ foliation.

Within SC garnet mica schist sericitic white mica grow syn-kinematically with $\mathrm{S}_{2}$ together with the outer rim of garnet porphyroblasts and minor biotite. In the amphibole-bearing mica schists («Horneblendegarbenschiefer» Auct.) biotite replaced amphibole porphyroblasts during $\mathrm{S}_{2}$ development, whereas a new generation of amphibole is seen to has grown late- to post- $S_{2}$.

The $S_{2}$ foliation displays a mylonitic character close to the TC-SC contact, on the northern slope of the Pfossen valley. Where the $S_{2}$ foliation becomes mylonitic a poorly developed $\mathrm{L}_{2}$ mineralogical lineation is locally visible. $\mathrm{L}_{2}$ is either marked by biotite millimetric flakes (q $2675 \mathrm{~m}$, near Eisjochl) or by the iso-orientation of centimetric amphiboles in garnet amphibolites (between 2350 and $2450 \mathrm{~m}$ on the path running along the bottom of the Pfossen valley). $\mathrm{L}_{2}$ is set at a very small, but clearly distinguishable, angle with the $\mathrm{D}_{3}$ crenulation axes. The $\mathrm{L}_{2}$ trend is roughly constant around $310^{\circ}$, with plunge ranging from $35^{\circ}$ to $90^{\circ}$ (fig. 5).

Several mylonitic shear zones, up to 5-10 metres thick and related to the $\mathrm{D}_{2}$ deformational phase, are present also within the SC basement (Pian del Catino and south ridge of Höhe Wilde). The mylonitic shear zones display transitional boundaries with surrounding rocks preserving a S-tectonitic fabric (fig. 6a). Thin, some centimetrethick, mylonites are present also within marble levels and are recognizable from their lighter colour and fine grain size, sometimes accompanied by submillimetric micarich layers, produced by mineralogical differentiation processes during mylonitization (fig. 6b). A poorly prominent NW trending lineation is visible on some outcrops, located just above the Stettiner Hutte. Similar centimetrethick shear zones occurring within mica schists are faintly visible and discontinuous.

Sin- $\mathrm{D}_{2}$ mylonites from both TC ans SC rocks display a strong grain size reduction and it is often difficult to recognize their protolith. Mylonitic foliation dip directions range between $300^{\circ}$ and $355^{\circ}$; the stretching lineation trends about $300^{\circ}$ with plunges of $40^{\circ}-50^{\circ}$ (fig. 5). Locally $\mathrm{s}-\mathrm{c}$ and s-c' structures occur, suggesting an extensional kinematic with a «top-to-NW» displacement. The mylonitic foliation is marked by biotite and white mica, consistent with P-T conditions of the $\mathrm{D}_{2}$ stage. Rarely garnet and biotite porphyroblasts are partly replaced by chlorite aggregates, suggesting greenschists facies re-activation of such shear zones during post- $\mathrm{D}_{2}$ evolution.

$\boldsymbol{D}_{3}$ - The $\mathrm{D}_{3}$ deformation phase deeply influenced the previous structural pattern. It is responsible for S- to SEverging asymmetric folds (fig. 5), developed from the outcrop to the regional scale. $\mathrm{D}_{3}$ folds are moderately to very tight, with interlimb angles around $40^{\circ}$. The S-verging orientation of $\mathrm{D}_{3}$ folds, together with a prevalent «Z» asymmetry produces the dominance of long limbs of the mesoscopic folds. This feature is widespread in the area between the SC to the north and the Passeier valley to the south (GREGNANIN et alii, 1995). A centimetre spaced $\mathrm{D}_{3}$ crenulation is present in mica-rich lithologies and calc-schists of both SC and TC (Schrotterwand, Schwarzwand, upper Lazins valley). The $\mathrm{S}_{3}$ foliation is marked by the preferred orientation of biotite and white mica in mica schists and 

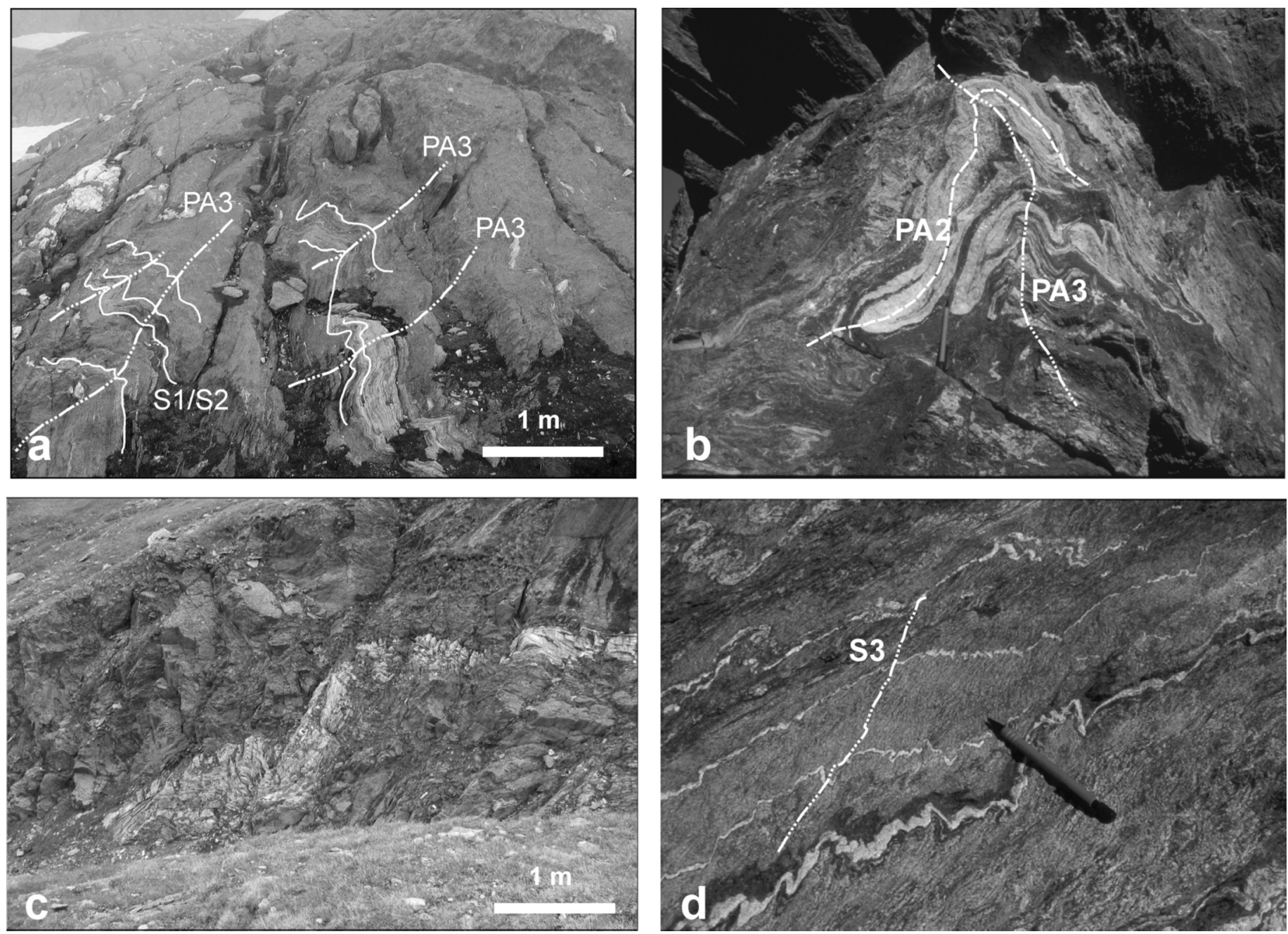

Fig. 7 - (a) $\mathrm{D}_{3}$ folds crenulating $\mathrm{S}_{2}$ foliation within Texel mica schists; upper Tel valley; $(b)$ Superposed $\mathrm{D}_{2}$ and $\mathrm{D}_{3}$ folds, the interference pattern is of the type 3 of RAMSAY \& HUBER (1987), with parallel fold axes and perpendicular axial planes; $(c) \mathrm{D}_{3}$ folds in the marble layers close the Texel-Schneeberg boundary, Pfossen valley; $(d) \mathrm{S}_{3}$ developed in amphibolic schists; Lazins valley.

- (a) Crenulazione $D_{3}$ che interessa la foliazione $S_{2}$ nei micascisti del Complesso di Texel, alta valle di Tel; (b) Figure di interferenza del tipo 3 (RAMSAY \& HUBER, 1987) date dalla sovrapposizione di pieghe $D_{2}$ e $D_{3}$, i due sistemi sono coassiali con piani assiali perpendicolari fra loro; (c) Pieghe $D_{3}$ nei marmi in prossimità del contatto fra i complessi di Texel e Schneeberg, Val di Fosse; (d) Foliazione $S_{3}$ negli scisti anfibolici, alta Val di Lazins.

paragneisses, and actinolitic amphibole in amphibolic schists (fig. 6d). Mineral assemblages related to $D_{3}$ suggest that an upper greenschist to epidote amphibolite facies metamorphic conditions was assisting this deformation.

$\mathrm{A} \mathrm{L}_{3}$ crenulation lineation is well developed in micarich lithologies and follows the same trend as $\mathrm{D}_{3}$ fold axes. $\mathrm{D}_{3}$ structures show a progressive steepening moving westward from the Höhe Wilde to the lower Pfossen valley, culminating in a zone, NW of Schrotterwand, with near-vertical fold axes and axial planes developed over a neat lithostratigraphy, forming the so called «Schlingen» (SANDER, 1921) (fig. 8d). The $\mathrm{D}_{3}$ axial planes in the «Schlingen» zone trend between NW-SE to WNW-ESE. SCHMIDEGG (1933) interpreted these structures as characteristic of middle crust conditions. Our structural analysis suggest $\mathrm{s}$ that they have been produced by the interference of $D_{2}-D_{3}$ folds, as previous envisaged by others authors (VAN Gool et alii, 1987) and are not directly connected with any particular P-T conditions.

$\boldsymbol{D}_{4}$ - The $\mathrm{D}_{4}$ deformation phase led to the development of centimetre to metre-scale kink-bands and shear zones.
The analyses of $\mathrm{D}_{2}$ and $\mathrm{D}_{3}$ structural data on stereographic projections together with foliations and axial planes traces on structural map (plate 1), indicate the existence of $\mathrm{D}_{4}$ folds developed at kilometre scale, responsible for trend variation of $\mathrm{S}_{2}$ and $\mathrm{D}_{3}$ axial planes. A possible $\mathrm{D}_{4}$ vertical dipping axial plane runs along the bottom of the Pfossen valley, with an approximately E-W trend. $\mathrm{D}_{4}$ structures are not easily observable in the study area, whereas they are more recognizable in the neighbouring areas, especially moving southward. They consist in metric to kilometre-sized open folds with subvertical axial planes, trending approximatively E-W, which often show fracture cleavage in hinge zones and rarely a poor developed foliation marked by chlorite and white mica.

$\boldsymbol{D}_{5}$ - The later stages of deformation occurred at low $\mathrm{P}$ and low T, mainly under brittle conditions. Faults accompanied by centimetre- to metre-thick cataclastic zones, with a dominant NE-SW trend, are widespread in the whole area, more abundant in the NE part of the study area. The cataclastic zones are often superposed on $\mathrm{D}_{2}$ mylonites, displaying the same trend but with a nearly vertical dip. Where vis- 

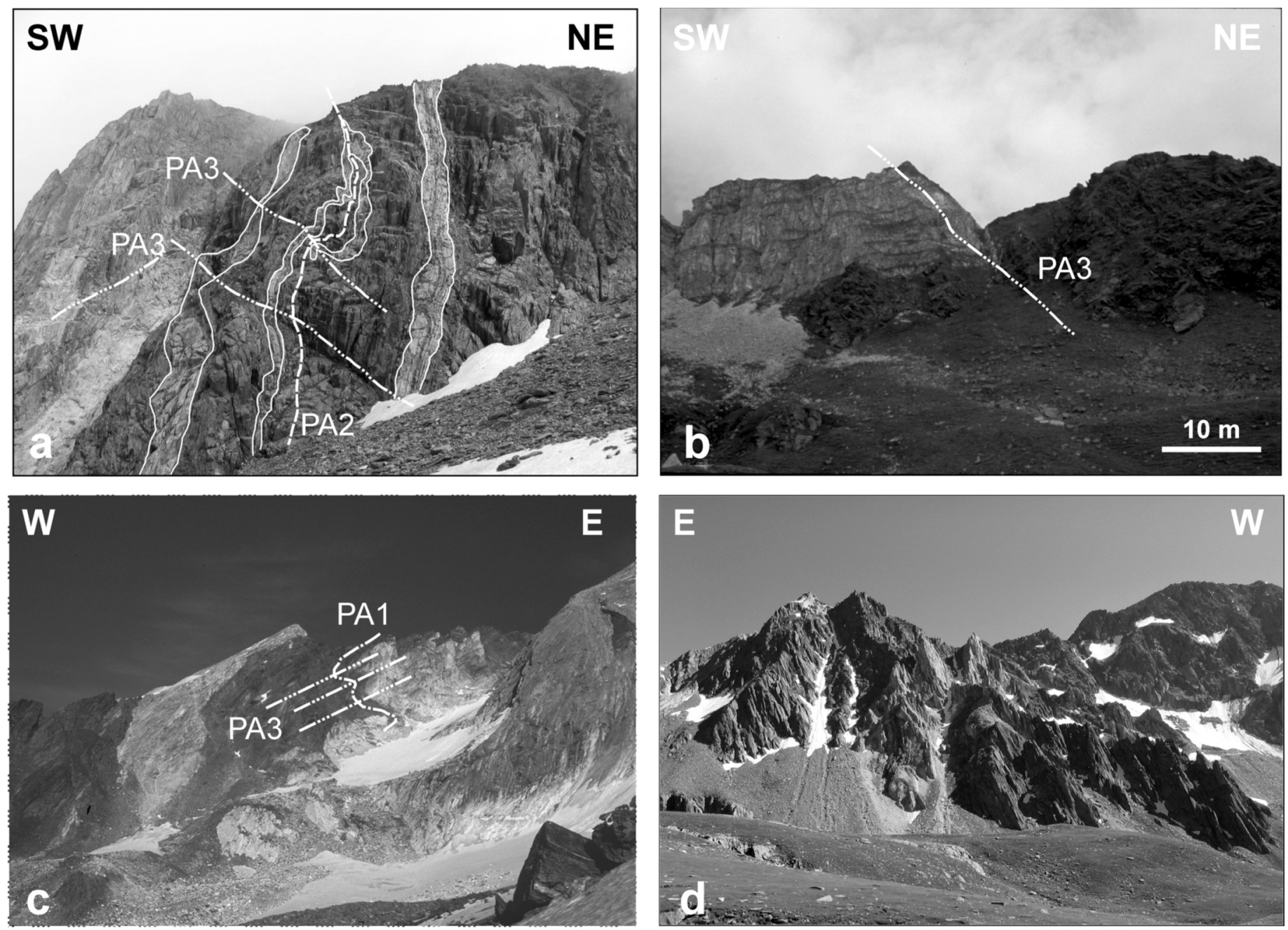

Fig. 8 - (a) $\mathrm{D}_{2}$ and $\mathrm{D}_{3}$ folds in marble layers on the $\mathrm{S}$ face of the Kleine Weiße; Tel valley; $(b) \mathrm{D}_{3}$ fold at the closure of the marble layer of the Lodner peak; Lazins valley; $(c) \mathrm{D}_{3}$ structures crosscutting $\mathrm{D}_{1}$ ones in calcschists and marbles on the S face of Grava peak; $(d) \mathrm{D}_{3}$ «Schlingen» folds in marbles and micaschists of the Schrotter peak, at the SW termination of the Schneeberg Complex, note the near vertical dipping of the marbles/gneisses lithological contact, that represents also the Texel-Schneeberg boundary.

- (a) Pieghe $D_{2}$ e $D_{3}$ nei livelli di marmo della parete $S$ della Cima Bianca Piccola; (b) Piega $D_{3}$ che interessa la chiusura della sinforme $D_{2}$ dei marmi della Cima Fiammante; (c) Pieghe $D_{3}$ sovraimposte a strutture $D_{1}$ sulla parete $S$ della Cima Grava; (d) Pieghe $D_{3}$ a laccio ad assi quasiverticali («Schlingen») che interessano i livelli di marmo e calcescisti alla base della Croda Rotta. Si noti la giacitura vicino al verticale del contatto fra marmi e gneiss, che rappresenta anche il limite fra il Complesso di Texel e quello di Schneeberg.

ible, slickensides point to a dominant left-lateral kinematic, locally with an extensional component.

Another fault system, with no direct correlation with the previous, trends NNE-SSW and includes some relevant structures such as the Johannes Schartl fault (fig. 8 b). It is an oblique fault with a NNE-SSW trending fault plane which dips to the $\mathrm{W}$ with angle around $75^{\circ}$. The vertical offset is around $100 \mathrm{~m}$. Some minor structures, belonging to the same fault system are present at the Grava Schartl and $700 \mathrm{~m} \mathrm{~W}$ of Eisjochl; in both cases the vertical and horizontal offset is around $10-20 \mathrm{~m}$.

\section{SUMMARY AND CONCLUSIONS}

On the base of field observations, the structural pattern of the study area is substantially homogeneous.

Four distinctive ductile deformational phases have been recognized, three of which accompanied by metamorphic recrystallisation.
The $\mathrm{D}_{1}$ structures in the Texel Complex are well recognisable as a relict foliation $\left(S_{1}\right)$ and rootless folds, preferably preserved within mica-poor lithologies. $\mathrm{S}_{1}$ and $\mathrm{S}_{2}$ are virtually indistinguishable in the $\mathrm{D}_{2}$ fold limbs, at least in the field, because the $\mathrm{D}_{2}$ event has intensively dissected and reoriented all the previous structures. Complex superposed folding, attributed to $\mathrm{D}_{1}$ and $\mathrm{D}_{2}$ interference, occur on the SE face of the Höhe Weiße, on the S face of the Grafen peak and on the SW face of the Lodner peak. The fold interference pattern between $D_{1}$ and $D_{2}$ folds is of type 3 of RAMSAY \& HUBER (1987).

In the Schneeberg Complex the pre- $\mathrm{D}_{2}$ structures are less well preserved than in the TC. Relict foliation and small rootless folds are rarely preserved only within mica-poor lithologies. On the base of field evidence a direct correlation between the $\mathrm{D}_{1}$ structures of the TC and the pre- $\mathrm{D}_{2}$ relics in the SC is not possible. Moreover the suggested P-T conditions of the metamorphism accompanying the $\mathrm{D}_{1}$ event in the Schneeberg and Texel basement are slightly different, with higher temperature 
for the TC. In the Spronser valley area, just a few kilometres to the south and south east of the study area, inferred $\mathrm{P}-\mathrm{T}$ conditions of the syn- $\mathrm{D}_{1}$ metamorphic event in the TC are of $640-680{ }^{\circ} \mathrm{C}$ and $0.9-1.0 \mathrm{GPa}$ (Spalla, 1993), whereas KonZETT \& HoINKES (1996) report 550 $600{ }^{\circ} \mathrm{C}$ and $0.8-1.0 \mathrm{GPa}$ for the syn-D1 metamorphic in the SC basement of Seeber valley (few kilometres to the north east of the Pfossen valley).

During the $\mathrm{D}_{2}$ event an axial plane foliation, $\mathrm{S}_{2}$, developed both in the Schneeberg and Texel basement. The $S_{2}$ foliation tends to become mylonitic close to the contact between the two units, suggesting that during, or in the late stages of the $\mathrm{D}_{2}$ phase, the tectonic coupling of the Texel and Schneeberg complexes took place.

Syn- $\mathrm{D}_{2} \mathrm{P}-\mathrm{T}$ conditions for the TC ranges between 550 $580{ }^{\circ} \mathrm{C}, 0.6-0.75 \mathrm{GPa}$ (SPALLA, 1993) and 640-680 ${ }^{\circ} \mathrm{C}, 0.5-$ $0.7 \mathrm{GPa}$ (ZANCHETTA, 2002). The syn-D2 metamorphism in the basement rocks of the SC took place at similar pressure and temperature of $520-560{ }^{\circ} \mathrm{C}$ and $0.7-1.0 \mathrm{GPa}$ (LANGONE, 2008). A late- to post- $\mathrm{D}_{2}$ temperature increase $\left(580-620{ }^{\circ} \mathrm{C}\right.$ at $\left.0.5-0.8 \mathrm{GPa}\right)$ within the $\mathrm{SC}$ was envisaged by the presence of sillimanite growing after kyanite porphyroblasts parallel to the $S_{2}$ foliation in the garnet mica schists of the Seeber valley (ZANCHETTA et alii, 2007; LANGONE, 2008).

The $\mathrm{D}_{3}$ event is responsible for the development of asymmetric S- to SE-vergent folds both at the outcrop and regional scale. Peculiar folds with subvertical axes, "schlingen", occur in the Pfossen valley and have been attributed to the $D_{2}-D_{3}$ interference pattern. The geometrical characteristic and orientation of the $\mathrm{D}_{3}$ structures are almost constant from the SC to the Passeier Line, as confirmed by structural analyses performed in this work and by previous authors (SPALLA, 1993; GREGNANIN et alii, 1995; GREGNANIN \& VALLE, 1995; SöLVA et alii, 2001; Sölva et alii, 2005; ZanchetTA, 2002). The $\mathrm{D}_{3}$ event occurred at upper greenschists facies conditions with $\mathrm{T}<500{ }^{\circ} \mathrm{C}$ and $\mathrm{P}<0.4 \mathrm{GPa}$ (HoInkes et alii, 1987; ZANCHETTA, 2002; Sölva et alii, 2005).

$\mathrm{D}_{4}$ folds and successive brittle structures affected the existing structural pattern only in a lesser extent.

Field relations and structural analysis of fabric elements at the meso- and micro-scale suggest that the Texel and the Schneeberg complexes experienced a common tectonic evolution at least since the $\mathrm{D}_{2}$ deformational phase under amphibolite facies conditions. The syn- $\mathrm{D}_{2}$ mylonites at the TC-SC contact and within the SC itself testify the presence of a major extensional shear zone, identified by SöLva et alii (2005) with the whole SC (SNFZ: Schneeberg Normal Fault Zone), along which the SC moved to the NW with respect to the TC. Fold style and $\mathrm{S}$ to SE sense of asymmetry of the $\mathrm{D}_{3}$ structures are coherent with the progressive extrusion of the TC basement in the footwall of the SC.

A major problem of this interpretation is tracing the continuation of the extensional shear zone between the SC and the TC to the west of the Pfossen valley, where the SC dies out and the polymetamorphic basement, with a dominant Variscan metamorphic imprint, of the Ötztal-Stübai Complex directly overlies the Texel Complex. Evidence of such shear zone progressively disappear already close to the SW termination of the SC (Schrottner peak), still in the study area of this work, possibly due to a stronger recrystallization of $S_{2}$ fabric during $\mathrm{D}_{3}$ deformation.
To conclude: still more research with detailed structural analyses, most of all focussed on the contact between the Texel basement and the Ötztal-Stübai Complex, are needed to test the previous interpretation. The relationships between the $\mathrm{D}_{2}-\mathrm{D}_{3}$ deformational event and the thrusting of the Ötztal-Stübai over the tectono-metamorphic units of the SC and TC with their metamorphism of alpine age are still poorly investigated. Unravelling such relations is of fundamental importance in the definition of the exhumation history and mechanisms of the Schneeberg and Texel complexes and could give important clues for the interpretation of the alpine geodynamic evolution of this sector of the Eastern Alps.

\section{ACKNOWLEDGEMENTS}

This work forms part of a PhD study (University of Milano) by S.Z. and also part of the CARG project «Foglio 013-Merano» of the Autonome Provinz und Bozen. G. Gosso, M.I. Spalla and P. Conti are gratefully acknowledged for comments and suggestions on an early version of the paper. Discussions with G. Gosso helped the author to clarify the concept of «tectonic transposition». S.Z. also warmly thanks A. Zanchi, S. Poli, V. Mair and A. Gregnanin for helpful discussions.

\section{REFERENCES}

Bell T.H. (1986) - Foliation development and refraction in metamorphic rocks: reactivation of earlier foliations and decrenulation due to shifting patterns of deformation partitioning. J. Metamorphic Geol., 4, 421-444.

Bell T.H. \& Rubenach M.J. (1983) - Sequential porphyroblast growth and crenulation cleavage development during progressive deformation. Tectonophysics, 92, 171-194.

VAN Gool J.A.M., Kemme M.M.J. \& Schreurs G.M.M.F. (1987) Structural investigations along an $E-W$ cross section in the Southern Oetztaler Alps. In: Flugel H.W., Faupl P. (Eds). Geodynamics of the Eastern Alps. Deuticke, Vienna, 214-225.

Gregnanin A., Barattieri M., Corona P. \& Valle M. (1995) Deformation and metamorphism in the Austroalpine OetztalStubai complex. Part I. The basement. Boll. Soc. Geol. It., 114, 373-392.

GREGNANIN A. \& VALLE M. (1995) - Deformation and metamorphism in the Austroalpine Oetztal-Stubai complex. Part II. Early-Alpine evolution in the basement and cover. Boll. Soc. Geol. It., 114, 393-409.

Konzett J. \& Hoinkes G. (1996) - Paragonite-hornblend assemblages and their petrological significance; an example form the Austroalpine Schneeberg Complex, souther Tyrol, Italy. J. Metamorph. Geol., 14 (1), 85-101.

KRETz R. (1983) - Symbols for rock-forming minerals. Am. Min., 68 (1-2), 277-279.

Habler G., THÖNI M. \& Sölva H. (2006) - Tracing the high pressure stage in the polymetamorphic Texel Complex (Austroalpine basement unit, Eastern Alps): P-T-t-d constraints. Mineral. Petrol., 88, 269-296.

HAMmer W. (1912) - Geologische Spezial Karte 1:75.000 Glurns-Ortler und Erläuterungen. Wien.

HobBs B.E., Means W.D. \& Williams P.F. (1976) - An outline of structural geology. Wiley. New York, $571 \mathrm{pp}$.

Hoinkes G., Frank W., Mauracher J., Peschel R., Purtscheller F. \& TessadRI R. (1987) - Petrography of the Schneeberg Complex. In: Flügel H.W., Faupl P. (Eds). Geodynamics of the Eastern Alps. Deuticke, Vienna, pp. 190-199.

Hoinkes G., Kostner A. \& Thöni M. (1991) - Petrologic Constraints for Eoalpine Eclogite Facies Metamorphism in the Austroalpine Oetztal Basement. Mineral. Petrol., 43, 237-254.

Hoinkes G., Koller F., Rantitsch G., Dachs E., Hock V., NeUBAUER F. \& SCHUSTER R. (1999) - Alpine metamorphism of the Eastern Alps. Schweiz. Mineral. Petrogr. Mitt., 79, 155-181.

LANGONE R. (2008) - Evoluzione tettono-metamorfica delle metapeliti dell'Unità di Monteneve (Valle del Lago, dominio Austroalpino 
delle Alpi centro-orientali). Università degli Studi di Milano, Diploma Thesis.

MAURACHER J. (1981) - Alpidische und voralpidische Metamorphose und Strukturpraegung am Westende des Schneebergerzuges (Oetztaler Alpen). Mitt. Ges. Geol.-Bergbaustud., 27, 244-245.

Poli S. (1991) - Reaction spaces and P-T paths: from the amphibole eclogite to greenschist facies in the Austroalpine domain (Oetztal complex). Contrib. Mineral. Petrol., 106, 399-416.

RAMSAY J.G. \& Huber M.I. (1987) - The techniques of modern structural geology. 2. Folds and Fractures. Academic Press, 309-700, London.

SANDER B. (1921) - Tektonik der Schneeberger Gesteinszuges zwischen Sterzing und Meran. Jb. Geol. B.-A., 70, 325-334.

SCHMID S.M. \& HAAS R. (1989) - Transition from near-surface thrusting to intrabasement decollement, Schlinig thrust, Eastern Alps. Tectonics, 8 (4), 697-718.

SchmidegG O. (1933) - Neue Ergenbnisse in den südlichen ÖtztalerAlpen. In Verhandlugen Geol. B.-A., 83-85.

Sölva H., Grasemann B., Thöni M. Thiede R. \& Habler G. (2005) - The Schneeberg Normal Fault Zone: Normal faulting asociated with Cretaceous SE-directed extrusion in the Eastern Alps (Italy/Austria). Tectonophysics, 401 (3-4), 143-166.

Spalla M.I. (1990) - Polyphased deformation during uplift of metamorphic rocks: the example of the deformational history of the Texel Gruppe (Central-Western Austroalpine domain of the Italian Eastern Alps). Mem. Soc. Geol. It., 45, 125-143.
SPALla M.I. (1993) - Microstructural control on the P-T path construction in the metapelite of the Austroalpine crust (Texel Gruppe, Eastern Alps). Schw. Min. Petrogr. Mitt., 81, 197-212.

SPIESS R. (1995) - The Passeier-Jaufen Line: a tectonic boundary between Variscan and an eo-Alpine Meran-Mauls basement. Schweiz. Mineral. Petrogr. Mitt., 75, 413-425.

Spiess R., Peruzzo L., Prior D.J. \& Wheeler J. (2001) - Development of garnet porphyroblasts by multiple nucleation, coalescence and boundary misorientation-drive rotations. J. Metamorphic. Geol., 19 (3), 269-291.

Viola G., Mancktelow N.S. \& Seward D. (2001) - Late OligoceneNeogene evolution of Europe-Adria collision: new structural and geochronological evidence from the Giudicarie fault system (Italian Eastern Aps). Tectonics, 20 (6), 999-1020.

ZANCHETTA S. (2002) - Evoluzione metamorfica delle metapeliti dell'Oetztal meridionale (Val Passiria). Diploma Thesis. Università degli Studi di Milano.

ZANCHETTA S. (2007) - Evoluzione tettonometamorfica delle unità di Texel e dello Schneeberg (Alpi Orientali). Rend. Soc. Geol. It., 4, Nuova serie, 312-314.

Zanchetta S., Langone R., Mair V. \& Poli S. (2007) - First report of sillimanite within the metapelites of the Schneeberg Complex. Mitt. Österr. Miner. Ges., 153, S. 137.

Zanchi A., Salvi F., Zanchetta S., Sterlacchini S. \& Guerra G. (2009) - 3D reconstruction of complex geological bodies: examples from the Alps. Computer \& Geosciences, 35, 49-69. 